\title{
Quality Assessment of Honey Sourced from Natural and Artificial Apiaries in Ekiti State, Nigeria.
}

\author{
Oyeyemi Sunday Dele*
}

Department of Plant Science, Ekiti State University, Ado-Ekiti 36001, Nigeria

\begin{tabular}{l}
\hline A R T I C L E I N F O \\
Research Article \\
Received 24 September 2016 \\
Accepted 06 September 2017 \\
\hline
\end{tabular}

Keywords:

Honey

Physicochemical

Mineral composition

Organoleptic

*Corresponding Author:

E-mail: sundaydeleoyeyemi@gmail.com

\begin{abstract}
A B S T R A C T
Honey samples were obtained from wild and domesticated sources and analyzed for some physicochemical properties such as color, $\mathrm{pH}$, moisture content, ash content, refractive index, specific gravity, total solid, viscosity, glucose and fructose content following Standard Association of Official Analytical Chemistry. The following range of values for $\mathrm{pH}$ (3.55-4.20), moisture content (18.50-25.60\%), soluble solids (74.10-81.20\%), ash content $(0.08-0.14 \%)$, specific gravity (1.38-1.47), refractive index (81.3-83.4\%), fructose content (40.5-63.04\%) and glucose content (19.35-32.34\%). The mineral composition analyzed revealed potassium to be the dominant mineral in the honey samples followed by Calcium. However, Cadmium and lead where not detected in the honey samples. The results indicated that parameters such as $\mathrm{pH}$, moisture content, ash content, specific gravity, sugar (majorly fructose and glucose content), fructose/glucose ratio, glucose/water ratio conform within the limit of the international standard for honey. However, moisture contents of the wild honey samples $(22.05 \%$ and $25.60 \%)$ were a little higher than the Codex Standards of $\leq 21 \%$. In conclusion, the honey samples investigated have the needed quality criteria and are good for human consumption. The results also revealed excellent organoleptic acceptability of the honey samples, hence are suitable for human uses.
\end{abstract}

DOI: https://doi.org/10.24925/turjaf.v5i10.1125-1129.991

\section{Introduction}

Honey is one of the most important processed foods that are rich in carbohydrate, amino acids, proline, essential minerals and vitamins provided by the nature to the human body. Honey is produced in Nigeria by honey bee species Apis mellifera and variety adansonii. Bees forage for different plant species both nectariferous and non necteriferous to produce different honey that varies in quantity, quality, color and flavor. Honey is considered as a very complex food product with an unusual composition. Its composition and characteristics are due to its geographical origin and different plant species that bees visit during honey production (Joseph et al., 2007). Despite the geographical differences, the main constituents of honey will remain the same (Terrab et al., 2003). Honey composition and quality also depend on several other factors such as humidity inside the hive, nectar sources, methods employed during honey extraction and storage. The beneficial and medicinal properties of honey have been appreciated all over the world for several thousand of years. Honey has not only been used as a sweetener in food, but also for therapeutic and religion purposes since millennia (National Honey
Board, 2002). Traditionally, honey has been reported as a plant product with good medicinal remedy for the treatment of wounds and various ailments such as cough, (Abell et al., 1996), constipation, diabetes, sore, arthritis (Famuyide et al., 2014) as well as skin diseases. Many researchers such as Adenekan et al. (2012) and Nnwanko et al. (2014) reported that the healing capacity of honey is strongly influenced by its physical and chemical properties. The belief that honey is a food, drug and an ointment has been carried into our days. Several workers reported that honey serves as part of raw materials for food, pharmaceutical, cosmetic and beverages industries (Ojeleye, 1999). Honey has both social and economic benefits. It has received much attention particularly at the commercial level in Nigeria. Honey consumers are particularly interested in the quality and source of the honey they buy. They rely on the physical characteristics such as color, aroma, and conventional methods in discerning good quality honey. Neither the taste, visual, or physical aspect of honey are enough to discern which region the honey is produced. Physicochemical properties such as ash content, $\mathrm{pH}$, moisture content, total solid, 
proline content, viscosity, refractive index and total sugar are important criteria for the determination of good quality honey.

Interestingly, Ekiti State which falls in the rainforest ecological zone of Nigeria has great potential for beekeeping (Kayode and Oyeyemi, 2014). In recent time, there has been an increase in production and demand for honey in the state. The demand for honey is increasing everyday due to its nutritive and medicinal value. The major limiting factor to the acceptability of honey from this area is the fear of adulteration which led to lack of confidence in the product. Pure honey is scarce and most of what is sold locally in Nigeria is caramelized sucrose (Omode and Ademukola, 2008). There is a need to verify the source of the product. This will help to reveal the possible presence of adulterants (sugar or caramel) during honey processing. Assessing honey for quality control purposes requires determination of its $\mathrm{pH}$, moisture, ash, total solids, sugar content (sucrose, glucose and fructose), viscosity, refractive index and specific gravity.

Several researchers have worked on the quality assessment of honey from various geographical locations in Nigeria. The physical characteristics of four honey samples from North-Central Nigeria have been reported by James et al. (2009). Quality assessment of natural honey from Adamawa State, North Easter Nigeria was documented by Igwe et al. (2012). The study of the physicochemical analysis of honey produced from Hawan Kibo hills in the Plateau State of Nigeria was reported by Anhwange et al. (2015). The physicochemical assessment of commercial honey from Edo State, Nigeria was carried out by Oshomah and Agbaji (2015). There is inadequate information on the physical and chemical properties of honey from Ekiti State, Nigeria. This study was conducted with aim of determine the physicochemical properties of honey from different sources (artificial hives and natural hives) in order to authenticate their quality.

\section{Materials and Methods}

Four honey samples were procured from local honey producers in Ado Ekiti, Ekiti State, Nigeria. Two honey samples were obtained from Ilawe road (samples A and B) and two samples (samples C and D) were obtained from Ago Aduloju, Ado Ekiti. The collected honey samples were stored in airtight plastic containers and later taken to Jagee Nig. Ltd. Ibadan, Oyo State, Nigeria for physicochemical analysis.

Physicochemical parameters such as $\mathrm{pH}$, moisture content, ash content, total solid, viscosity, Refractive index, specific gravity, glucose and fructose were determined.

\section{Determination of Color}

The color of the samples was determined by using the P-fund scale ( $\mathrm{mm})$. In order to analyze, $2 \mathrm{ml}$ of the honey sample was taken in a beaker, the instrument was calibrated and dipped into the sample while the readings were taken from the meter and compared (Terreb et al., 2004).

\section{Determination of Moisture Content}

Two grams each of the honey samples was weighed and transferred into a pre-weighed crucible. The crucible was kept in an oven at $100-105^{\circ} \mathrm{C}$ over night. After this, they were removed and cooled in a desiccator and reweighed. The loss in weight was then calculated as the percentage moisture content (AOAC, 1990) using the following formula:

Where;

$$
\mathrm{M}=\frac{\mathrm{WFH}-\mathrm{WDH}}{\mathrm{WFH}}
$$

M :Moisture (\%),

WFH :Weight of fresh honey sample,

WDH :Weight of dry honey sample,

\section{Determination of $\mathrm{pH}$}

The $\mathrm{pH}$ was determined using $\mathrm{pH}$ meter Model 610 by direct insertion into the honey samples.

\section{Determination of Ash Content}

For each test, $10 \mathrm{~g}$ of each sample was separately weighed in a crucible. The crucible was heated in a muffle furnace for about $3 \mathrm{hrs}$ at $500^{\circ} \mathrm{C}$. It was then cooled in a desiccator and weighed. To ensure that the ashing was completed, it was reheated again in the furnace for 30 minutes more cooled, weighed and repeated until the weight became constant (AOAC, 2000). The percentage ash content was calculated by the following formula:

here;

$$
\mathrm{A}=\frac{\mathrm{WAA}}{\mathrm{WBA}} \times 100
$$

M : Ash (\%),

WAA : Weight of sample after ashing,

WBA : Weight of sample before ashing,

\section{Determination of the Total Solid}

The percentage total solid of each honey sample was determined using the following formula:

Total solid $(\%)=100-$ Moisture content

\section{Determination of Viscosity}

Viscosity was determined using Brookefield Viscosity VHA 605-0109, USA with a spindle 62 at 20rpm. Results were obtained directly in units of Millipascal.

\section{Determination of Specific Gravity}

The specific gravity (SG) of the honey samples was obtained as the ratio of the weight of sample to that of an equal volume of water.

$$
\text { Specific gravity }=\frac{W s p-W p}{W w p-W p}
$$

Where;

Wp :Weight of the pycnometer

Wsp :Weight of sample + pycnometer

Wwp :Weight of water + pycnometer 


\section{Determination of the Refractive Index}

The refractive indices of the honey samples were measured at a room temperature of $20^{\circ} \mathrm{C}$ using an Abbe Refractometer (AOAC, 1990).

\section{Determination of the Total Titrable Acidity}

Twenty five milliliters of each sample (diluted) was titrated against $0.1 \mathrm{~N} \mathrm{NaOH}$ using phenolphthalein as an indicator, up to $\mathrm{pH} 8.3$ (Jacobs, 1999). The results were expressed in milliqualent of acid at $1 \mathrm{~kg}$ of honey.

\section{Glucose and Fructose Determination}

Glucose and Fructose content were evaluated following the method of Association of Analytical Chemist (AOAC, 2002).

\section{Determination of the Mineral Composition}

The mineral composition of the honey samples including $\mathrm{K}, \mathrm{Na}, \mathrm{P}$ and $\mathrm{Zn}$ were quantitatively determined using an atomic absorption spectrophotometer, after digestion by the wet ashing method (Escuredo et al., 2011).

\section{Results and Discussion}

The first physical observation of honey that is usually encountered by the consumers is its color (Bogdanov et al., 2004). The color of the honey varied from amber to light yellow to golden yellow to dark. Eleazu et al. (2013) reported that honey comes in different shades of color such as white, amber, red, brown and almost black. Our observations agree with the previous works of Archling (2007) and Kayode and Oyeyemi (2014). Colors of honey are influenced by several factors such as the nectar source, plant species, processing and packaging techniques. Dark honey has been reported to contain more minerals than light honey (White, 1975) as well as more phenolic acid derivatives but less flavonoid (Amiot et al., 1989).
The $\mathrm{pH}$ value of honey samples analyzed ranged from 3.55 - 4.40 with mean value of 4.02. This implies that all the honey samples were acidic. Published reports showed that the $\mathrm{pH}$ of honey should be between the range of 3.24.5 (Bogdanov, 1995). The results of our finding conformed to the acceptable range specified by Codex Alimentarium (2001). The $\mathrm{pH}$ values obtained in this study are low enough to prevent microbial growth especially in wound treatment.

The differences in the acid and minerals composition as well as floral variation may leads to differences in the $\mathrm{pH}$ values.

The moisture content of the honey samples A and B fall below the maximum value of $21 \%$ moisture content as prescribed by Codex Alimentarium (2001) and EU Commission (2002). Honey sample C and D (wild honey) have values $22.05 \%$ and $25.60 \%$ respectively which are higher than the $21 \%$ maximum value. This may be attributed to the high relative humidity of the area where the honey was obtained as well as processing and storage defects. Moisture content plays an important role in honey viscosity, taste and shelf life (Kayode and Oyeyemi, 2014).

The values reported for ash content for the four honey samples examined varied from $0.08 \pm 0.01 \%$ to $0.12 \pm 0.02 \%$. The results obtained in this study fall within the permissive range. The results obtained corroborate with the reports of Kayode and Oyeyemi, (2014) with range between $0.004 \%$ and $0.44 \%$ for honey samples from different locations in Ekiti State. Olugbemi et al. (2013) reported a range of $0.33 \%$ to $0.63 \%$.

Codex Alimentarium Commission (2014) proposed $\leq$ $0.6 \%$ ash content for normal honey. Viscosity values were found to be between $680.25 \%-781.40 \%$. Viscosity is one of the physicochemical parameter used to measure the quality of the honey sample. Pure honey has a high viscosity (Lawal et al., 2009). The high viscosity values obtained in this work is an indication that the honey had not been diluted with other products. Honey consists of sugars mostly glucose and fructose.

Table 1 Physicochemical compositions of honey from natural and artificial hives in Ekiti State, Nigeria

\begin{tabular}{l|cccc}
\hline \multirow{2}{*}{$\begin{array}{c}\text { Physichochemical } \\
\text { parameter/Honey samples }\end{array}$} & \multicolumn{2}{c}{ Artificial Hives } & \multicolumn{2}{c}{ Natural Hives } \\
\cline { 2 - 5 } Color & Golden yellow & Light yellow & Amber & Golden dark \\
$\mathrm{pH}$ & $4.2 \pm 0.0$ & $3.55 \pm 0.07$ & $4.40 \pm 0.14$ & $3.90 \pm 0.00$ \\
Moisture content (\%) & $18.50 \pm 0.0$ & $21.80 \pm 0.28$ & $22.08 \pm 0.07$ & $25.60 \pm 0.28$ \\
Ash content (\%) & $0.12 \pm 0.02$ & $0.10 \pm 0.01$ & $0.08 \pm 0.01$ & $0.14 \pm 0.00$ \\
Total soluble solid (\%) & $81.20 \pm 0.42$ & $78.60 \pm 0.21$ & $78.00 \pm 0.14$ & $74.14 \pm 0.14$ \\
Total Titratable Acidity (meq/kg) & $47.40 \pm 0.05$ & $20.40 \pm 0.26$ & $28.40 \pm 0.14$ & $16.90 \pm 0.14$ \\
Specific gravity & $1.38 \pm 0.02$ & $1.45 \pm 0.01$ & $1.47 \pm 0.04$ & $1.42 \pm 0.01$ \\
Refractive index (Brix \%) & $83.20 \pm 0.01$ & $82.60 \pm 0.28$ & $81.30 \pm 0.14$ & $82.50 \pm 0.0$ \\
Viscosity (mpas.) & $722.00 \pm 1.56$ & $635.00 \pm 7.07$ & $781.40 \pm 0.85$ & $704.66 \pm 13.19$ \\
Glucose (\%) & $19.35 \pm 0.50$ & $32.34 \pm 0.17$ & $34.86 \pm 0.20$ & $28.62 \pm 0.53$ \\
Fructose (\%) & $40.50 \pm 0.01$ & $41.71 \pm 0.85$ & $63.04 \pm 0.05$ & $50.90 \pm 0.03$ \\
Glucose +Fructose (\%) & $59.86 \pm 0.50$ & $74.05 \pm 0.26$ & $86.27 \pm 0.24$ & $82.02 \pm 0.23$ \\
Glucose/Fructose ratio & 2.1 & 1.3 & 1.9 & 2.0 \\
Glucose/Water ratio & 1.05 & 1.59 & 1.23 & 1.65 \\
\hline
\end{tabular}


Table 2 Mineral composition of honey from natural and artificial hives in Ekiti State, Nigeria

\begin{tabular}{l|cccc}
\hline Honey samples/ Mineral & \multicolumn{2}{|c}{ Artificial Hives } & \multicolumn{2}{c}{ Natural Hives } \\
\cline { 2 - 5 } \multicolumn{1}{c}{ elements $(\mathrm{mg} / \mathrm{kg})$} & $(\mathrm{A})$ & $(\mathrm{B})$ & $(\mathrm{C})$ & $(\mathrm{D})$ \\
\hline Calcium & $23.10 \pm 1.29$ & $20.36 \pm 0.17$ & $37.76 \pm 0.66$ & $40.90 \pm 0.14$ \\
Potassium & $1609 \pm 13.61$ & $1540.66 \pm 29.08$ & $1627.11 \pm 17.79$ & $1887.28 \pm 4.92$ \\
Phosphorus & $379.19 \pm 4.34$ & $418.90 \pm 3.28$ & $382.32 \pm 6.46$ & $300.76 \pm 0.74$ \\
Zinc & $7.47 \pm 0.35$ & $5.32 \pm 0.07$ & $3.34 \pm 0.10$ & $7.96 \pm 0.09$ \\
Cadmiun & $0.00 \pm 0$ & $0.00 \pm 0$ & $0.00 \pm 0$ & $0.00 \pm 0$ \\
Lead & $0.00 \pm 0$ & $0.00 \pm 0$ & $0.00 \pm 0$ & $0.00 \pm 0$ \\
\hline
\end{tabular}

All the honey samples analyzed contained more fructose than glucose which is an indication that the honey would be less prone to crystallization. Honey with high fructose to glucose ratio would remain liquid for a longer period. It is also a parameter that can be used to differentiate pure honey from commercial inverted sugar (White and Donner, 1980).

The sum of fructose and glucose for our investigated honey samples are within the proposed limit by the international norms $\geq 60 \mathrm{~g} / 100 \mathrm{~g}$. Beside the sum of fructose and glucose, another important factor in honey quality is the fructose/glucose ratio. Honey remains liquid at high fructose/glucose ratio. Honey crystallization is slow at ratio more than 1.3 (Amir et al., 2010). The result of fructose/glucose ratio falls in the range of 1.3 to 2.1 with mean value of 1.75 while the glucose/water ratio is within the range of 1.05 and 1.65 with average value of 1.39 .

The glucose/water ratio is considered more appropriate than the fructose/glucose ratio when considering honey crystallization. Amir et al. (2010) stated that there is no or little crystallization when G/W ratio is less than 1.3 and fast or almost complete at ratio greater than 2.0. The results of the specific gravity of the honey samples were higher (1.38-1.50) compared to other reports from other locations (Olugbemi et al., 2013) but compared favourably with a range of 1.42 to 1.44 (Ndife et al., 2014) as well as 1.299 to 1.315 (Igwe et al., 2012). Determination of honey specific gravity is an important parameter for its quality assessment. Total solid is a measure of dissolved solid in the honey samples. A reduction in the total solid of honey showed that the honey has been diluted. The results of this study with a range of $74.1 \%-83.75 \%$ and with mean value of $77.96 \%$ conformed to the total solid range of 58.4 to $80.0 \%$ as reported by Igwe et al. (2012) for Nigerian honey. The result obtained in this investigation is higher than the range of 11.33 to $21.30 \%$ reported for five honey samples from Umuachia, Nigeria (Olugbemi et al., 2013).

The mineral content of the honey samples showed that the highest mineral element was recorded for Potassium. Others were in order of Phoshorus > Calcium > Zinc. Several researchers had reported the dominant metals such as Potassium, Phosphorus, Calcium and Zinc in their previous studies (Agbagwa et al. (2011); Oyeyemi et al. (2015). The abundance of Potassium in all the honey samples analyzed is in agreement with the submission of Adebiyi et al. (2004); Agbagwa et al. (2011) and Ndife et al. (2014). They reported the dominance of Potassium in their previous studies on honey from different locations in Nigeria.

\section{Conclusion}

The result of our findings has shown that honey from artificial and natural apiaries are of good quality in respect to some important physicochemical parameters. The values of $\mathrm{pH}$, ash, glucose, fructose contents as well as glucose/fructose ratio fall within the prescribed international standard limit. Honey samples produce from this state are of good quality and can be exported if properly packed. In addition, there is a need for further physical/chemical investigation on more honey samples from this region to assess their quality and exportability.

\section{References}

Abell DC, Frube H, Schweger C, Kwok ASK, Sporns P. 1996. Comparison of processed unifloral clover and canola honey. Apidologie, 27: 451-480.

Adebiyi FM, Akpan I, Obianjuwa EI, Olaniyi HB. 2004. Chemical/physical characterization of Nigerian honey. Pak. J. of Nutr., 3: 278-281.

Adenekan MO, Amusa NA, Okpeze VE, Owosibo AO. 2012. Nutritional and microbiological components of honey samples obtained from Ogun State, Southwestern Nigeria, European J. of Sust. Dev, 1(2): 271-286.

Agbagwa, OE, Otokunefor TV, Frank-Peterside N. 2011. Quality assessment of Nigeria Honey and Manuka honey. J. Microbiol. Res, 1(3): 20-31.

Amiot MJ, Aubert S, Gonnet M, Tacchini M. 1989. Phelonic composition of honeys. Preliminary study on identification and group quantification, Apidologie, 20: 115- 125.

Amir Y, Yesli A, Bengana M, Sadoudi R, Amrouche R. 2010. Physico-chemical and microbiological assessment of honey from Algeria. Electr. J. Env. Agric. Food Chem, 9:1485-1494.

Anchling F. 2007. L'Abeille de France et t'apiculteur, 942: $495-$ 504.

Anhwange BA, Yiase SG, Aloo GH Anzaki AJ. 2015. Chemical study of natural and farmed samples of honey from Riyon, Plateau State. Int. J. Mat. Chem. Phy, 1(3):345-351.

AOAC. 1990. Food composition, additives and natural contaminants. In: Official Methods of Analysis. Helrich, K. (ed). Association of Official Analytical Chemists International 2, 15th Edition, Arlington, VA, USA.

AOAC. 2002. Sugar and sugar products. In: Official Methods of Analysis. Horwitz, W.(ed.). Association of Official Analytical Chemists International, Vol. 2 No. $44,16^{\text {th }}$ Edition, Washington, DC, 22-33.

Bogdanov S, Bieri K, Figar M, Figueiredo V, Iff D, Kanzig A, Stockl H, Zurcher, K, Miel. 1995. Definition et directives pour l'analyse et 1'appreciation centre Suisse deerecherché Apicole, Station de recherché laitieres. Liebefeid, Berne. 
Bogdanov S, Kaspar R, Livia PO. 2004. Physico-chemical methods for the characterization of Unifloral Honeys: A Review, Apidologie, 35: Pp S4-S17.

Codex Alimentarium Commission. 2001. Revised Codex Standard for Honey, Codex STAN 12-1981, Rev.1. (1987), Rev.2 (2010), FAO/WHO, 215.

Codex Alimentarius. 2004. Draft revisal standard for honey Codex Alimentarius Commission, FAO, Rome, Alinorm, 25: 19-26.

Eleazu CO, Iroaganachi M, Okoronkwo J. 2013. Determination of the physico-chemical composition, microbial quality and free radical scavaging activities of some commercially sold honey samples in Abia, Nigeria; 'The effect of varying colour'. International Journal of Biomedical. 4(1):32-41.

Escuredo O, Seijo M, Fernadez-Gonzalez M. 2011. Descriptive analysis of rubus honey from the north-west of Spain. Int. J. Food Sci. Tech, 46: 2329-2336.

EU Council. 2002. Council Directive 2001/110/EC of 20 December 2001, Revised Codex Standard for Honey. Standard and Standard Methods 11.

Famuyide OO, Adebayo O, Owese T, Azeez PA, Arabomen O, Olugbire OO, Ojo D. 2014. Economic contributions of Honey Production as a means of livelihood strategy in Oyo State, Int. J. Sci. Technol, 3(1):7-11.

Igwe EC, Dandago A, Binga EW. 2012. Assessment of quality attribution of natural honey from Adamawa State, North Eastern, Nigeria. Afr. J. Food Sci, 6(18): 449-455 Doi:10.5897/AJFS12.024

Jacobs BM. (1999). The Chemical Analysis of Foods and Food Products. $\left(3^{\text {rd }}\right.$ ed.) CBS Publishers and Distributors, New Delhi, India.

James OO, Mesubi MA, Usman LA, Yeye SO, Ajanaku KO. 2009. Physical characteristics of some honey samples from NorthCentral Nigeria. Int. J. Phys. Sci, (4): 464-470.

Joseph T, Awah-Ndukum J, Fonteh Florence A, Delphine ND, Jonnas P, Ze Antoine M. 2007. Physicochemical and microbiological characteristics of honey from the SudanGuinean Zone of West Cameroon. Afr. J. Biotech. 6 (7): 908913.

Kayode J, Oyeyemi SD. 2014. Physicochemical investigation of honey samples from bee farmers in Ekiti State, Southwest, Nigeria. J. Plant Sci. 2(5): 246-249. Doi:org/10.4236/fns. 2015.615140
Lawal RA, Lawal AK, Adekalu JB. 2009. Physicochemical studies on Adulteration of Honey in Nigeria. Pak. J. Bio. Sci, 12(15): 1080-1084.

Ndife J, Kida F, Makarti T. 2014. Quality assessment of Nigerian honey sourced from different floral locations. J. Food Nutr. Sci. 2(4):162.doi:10.11648/j.jfns.20140204.20

National Honey Board. 2002. Honey Health and Therapeutic qualities. http//www.nhb.org/infropub/month/2002/10_2002 monthly report pdf. Retrieved $29^{\text {th }}$ August, 2012.

Nwankwo CM, Ezekoye CC, Igbokwe SO. 2014. Phytochemical screening and antimicrobial activity of apiary honey produced by honey bee (Apis mellifera) on clinical strains of Staphyloccus aureus, Escherichia coli and Candida albicans. Afr. J. Biotech, 13(23): 2367-2372.

Olugbemi O, Ikeme,C H, Dioha IJ. 2013. Physicochemical analysis of honey from Umuahia, Abia-State, Nigeria. Res. J. Eng. Appl. Sci, 2(3):199-202.

Oshoma MU, Agbaji EB. 2015. Physicochemical assessment of commercial honey from Edo- State, Nigeria. Int. J. Appl. Sci. Eng. Res (IJASER) 4(1): 151-159.Doi: 10.688/ijaser.04015

Ojeleye B. 1999. Chemical composition of honey. The Beekeeper J.1:4-5

Omode PE, Ademukola SA. 2008. Determination of Trace Metal in Southern Nigerian Honey by use of Atomic Absorption Spectroscopy. Spectroscopy Lett., 41: 328-331.

Oyeyemi SD, Kayode J, Owolabi MO. 2015. Comparative nutritional studies on honey samples in Ado Ekiti, Ekiti State, Nigeria. Donnish J. Med. Plant Res, 2(2): 016-020.

Terrab AB, Valdes B, Diez DJ. (2003). Pollen analysis of honey from Mamora forest region (NW Morocco). Grana 42(1): 4754.

Terrab A, Recamales AF, Hernanz D, Heredia FJ. 2004. Characterization of Spanish thyme honey by their physicochemical characteristics and mineral contents. J. Food Chem, 4(88): 537-542.

White JW. (1975). Composition of honey, Physical characteristics of Honey. In: A comprehensive survey. Heinemann; Cabon.

White JW, Doner LW. 1980. Honey composition and properties: Beekeeping in the United States. Agriculture Handbook No. 338, Revised October, 82-91. 